\title{
Physicochemical and Hydrogeological Characteristics of Water Obtained From Borehole and Rivers in Okada and Environs, Edo State, Nigeria
}

\author{
OGIERIAKHI, OE; *ILEVBARE, M \\ Geology Department, University of Benin, Benin City, Edo State, Nigeria \\ *Corresponding Author's Email: ilevbaremartins777@gmail.com; Tel: +234905 7199940 \\ Other Author's Email: saxco4u@yahoo.com;Tel: +234906272 2449
}

\begin{abstract}
The consumption of unsafe water is detrimental to human health. It is therefore important to ascertain the quality and purity of water set out for drinking purpose. This paper therefore investigates the physicochemical and hydrogeological properties of water obtained from boreholes and rivers located at various sites in Okada town and environs, Edo State, Nigeria. The physicochemical parameters were analyzed using standard methods. Results obtained for the physicochemical properties showed that the concentration of phosphate, sulphates, nitrates and manganese in the samples range between $(0.0310-0.450) \mathrm{mg} / \mathrm{L},(0.05-1.01) \mathrm{mg} / \mathrm{L},(0.021-1.0) \mathrm{mg} / \mathrm{L}$ and $(0.01-0.41) \mathrm{mg} / \mathrm{L}$ respectively. The maximum concentration of calcium and sodium in all the samples analyzed was $1.27 \mathrm{mg} / \mathrm{L}$ and $8.65 \mathrm{mg} / \mathrm{L}$. Comparison of the $\mathrm{pH}$ value of the samples shows they are all acidic in nature, with $\mathrm{pH}$ values which ranges from $(4.3-6.0)$. In all the samples analyzed, it was observed that no trace of heavy metal (lead) was found except in Iguvinyoba River (down-stream) with a concentration of $0.001 \mathrm{mg} / \mathrm{L}$. The biological oxygen demand (BOD) and chemical oxygen demand (COD) values from all the water samples are below the WHO standard while the dissolved oxygen (DO) values are above the WHO standard. The results revealed that physicochemical parameters were slightly below WHO and NAFDAC standards for drinking water, except for the high iron (Fe) content at Usen. Thus from established standard, the borehole and river water in the study area will need some treatment to render it suitable for drinking.
\end{abstract}

\section{DOI: https://dx.doi.org/10.4314/jasem.v24i8.25}

Copyright: Copyright $(C) 2020$ Ogieriakhi and Ilevbare. This is an open access article distributed under the Creative Commons Attribution License (CCL), which permits unrestricted use, distribution, and reproduction in any medium, provided the original work is properly cited.

Dates: Received: 30 May 2020; Revised: 07 July 2020; Accepted: 09 August 2020

Keywords: physicochemical, hydrogeological properties, quality, drinking purpose, borehole and river water.

The quality of water over the decade had been described by the colorless, odorless, tasteless and its transparent character. It is a basic resource necessary for sustaining all human activities, so its provision in desired quantity and quality is of utmost importance (Taruna and Alankrita, 2013). The two major sources of freshwater are the surface water and groundwater. The groundwater provides a valued fresh water resource to human population and constitutes about two-third of the fresh water reserves presently occupying various spaces across the world (Adeyemi, et al., 2017). The deterioration of water quality has led to the destruction of ecosystem balance, contamination of soil and surface water sources (Faiza, et al., 2018). The physical, chemical, and biological parameters were often used to determine the safety of water required for consumption (Sivaranjani et al., 2015; Muhammad et al., 2013; Gorde and Jadhav, 2013; Sasikaran, 2012). Most developing and underdeveloped economy are faced with the challenge of lack of adequate, clean and safe water supply infrastructures. Nigeria, as a developing country is also striving hard to supply potable drinking water especially in rural areas where most people depend on ground and surface water for sustenance. Over the years the Nigerian government had put in place policies that could encourage the priority for the provision of safe, clean and adequate water especially in the rural areas, however the implementation of such policies was overwhelmed by the inadequacies of implementation of such policies (Nwankwoala, 2011). Groundwater is often the first alternative choice of many consumers due to its perceived cleanness and safeness. However, many studies have shown that groundwater can appear clean but contains a wide variety of contaminants (Olasoji et al., 2019; Vijaya and Sai, 2017; Sabrina et al., 2013; muhammad et al., 2013). Groundwater contamination occurs when pollutants are released and make their way down into the ground (Adeyemi et al., 2017). Main sources of groundwater contamination are from mine dumps, leach residue, landfills, leaking septic tanks, oil spillage, acid rain and host rock in which it is dug. Hence, the location of a borehole yet to be drilled should be well assessed in other to avoid water pollution that can pose as a threat to human lives. 
Contaminants such as heavy metals, lead, arsenic, chromium, cadmium and mercury are dangerous for human health when consumed at high concentration because they are toxic and can be carcinogenic (Doan et al., 2018; Malaysia et al., 2015). Owing to changes in environmental factors, a continuous water quality assessment should be carried out for provision of necessary information on the water quality and its suitability for domestic use. The objective of this paper is to assess the quality of water obtained for domestic consumption in Okada and environs of Edo State, south-south Nigeria by evaluating the physicochemical and hydrogeological characteristics of the water.

\section{MATERIALS AND METHODS}

Study Area: The study area is located in Ovia north east and part of Ovia southwest local government areas of Edo state (Fig 1), lies within longitude $5^{0} 19 \mathrm{E}$ and $5^{0} 30 \mathrm{E}$ and latitude $6^{0} 30 \mathrm{~N}$ and $6^{\circ} 45 \mathrm{~N}$. The study area cut across two local government areas of Edo state.

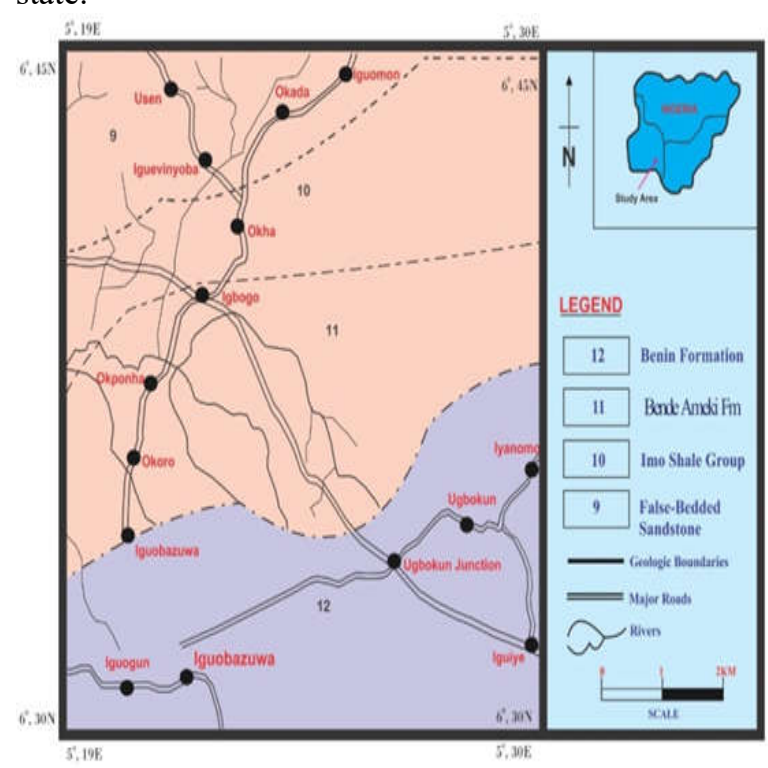

Fig 1: Geologic map of Okada and Environs

Sample Collection and Sample Analysis: A total of seven (7) water samples were collected within the study area. Four (4) of the sample were borehole sample, three (3) of the water sample were from rivers in the study area. The number of borehole sample collected was limited due to the fact that most of the boreholes in some of the villages were not working as at the time this work was carried out while in the field. The collected samples were taken to the laboratory for analysis. Physicochemical parameters were analyzed using Atomic absorption model SOLAAR 969 Unicam series.
Hydro-Geologic Setting and Aquifer Characteristic of Study Area: The water resources into the area of study can be grouped into surface water such as rivers, springs, lakes and groundwater. The surface water within the study area is mainly; Iguevinyoba river which covers the NW part of the study area and runs through the western part of the area. The river has many tributaries which include the Usen River, Okada River, Igbogo River, Iguevinyoba River, Oha River and Siloko River. Iguevinyoba River is a tributary of the Oha River which drains toward the Siloko River at the far south western direction. At the southeastern part of the study area the river drains towards the Osse River at the southeastern part of the study area.

Most part of the study area act as discharge zone from perched aquifers, water aquifers and confined aquifers as can be seen in Okada area of the study area. There is a relationship between surface water and groundwater, at some points the surface water act as discharge medium for ground water, while at other points, the surface water recharge ground water. The major source of recharge of ground water is rainfall.

The study area is within the tropical climate and experience heavy rainfall. The hydrogeology consists of multi aquifer system, drill logs and outcrops have also defined the presence of perches aquifer, semiconfined and confined aquifers. The log above collected from different part of the study area shown a literate cap of thickness ranging from up to $70 \mathrm{ft}$ within the study area. As can be seen in the logs, the aquifer thickness range from $166 \mathrm{ft}$ to $400 \mathrm{ft}$ at Usen, and 170 $\mathrm{ft}$ to $372 \mathrm{ft}$ at Iguobazuwa while at Okada it is artesian as the water flows out to the surface, thickness of aquifer is up to $530 \mathrm{ft}$.

Aquiferous material consist of medium to coarse grained, partially consolidated sand with sorting increasing with depth. Water in most area is under artesian condition and semi-artesian conditions due to the underlying nature of clay body which are well consolidated due to it over burden load making the water to be under high pressure below the ground giving rise to artesian condition when the aquifer is penetrated as mainly seen at Okada area. Depth to the water table very greatly and ranges from $170 \mathrm{ft}$ at Iguobazuwa to surface or near surface at Okada as a result of a sharp decay of hydraulic head. The formation from investigation can be said to be prolific although it consist of alternating layers of sand and clay body. The borehole logs (fig. 2) and the correlation of the borehole logs (fig. 3) of the area of study is hereby presented. 


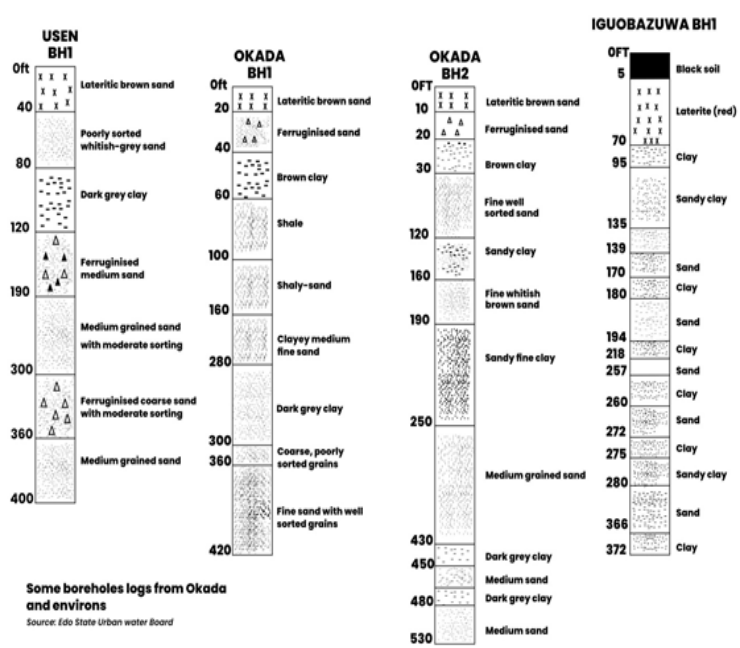

Fig 3: Lithologic correlation of Borehole logs from Okada and Environs

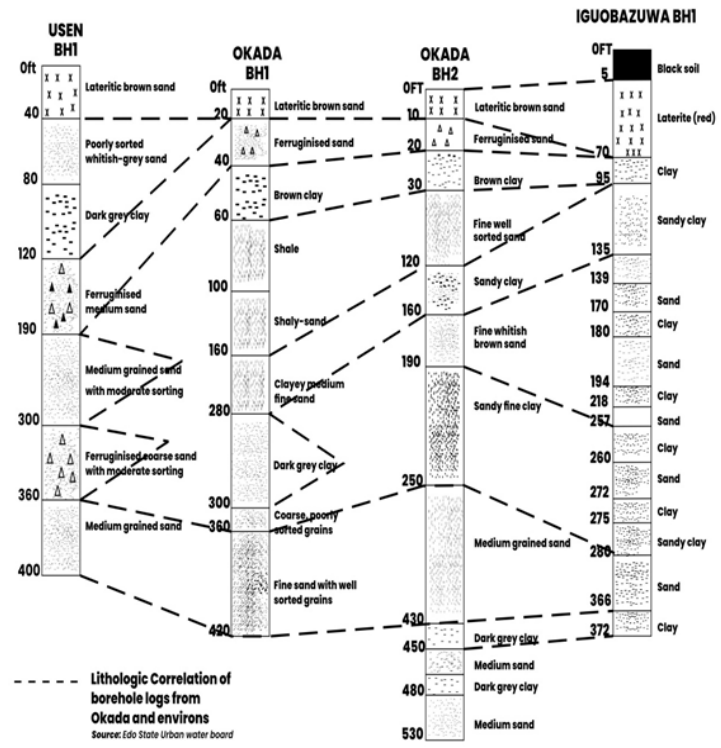

Fig 2: Lithologic Borehole logs of Okada and Environs.

\section{RESULTS AND DISCUSSION}

The Borehole samples at Okada, Iguobazuwa and Igbogo (tables 1-3) shows that all the physiochemical and geochemical parameters analysed for are below the NAFDAC and WHO standard for suitable drinking water except for the concentration Iron $(0.95 \mathrm{mg} / \mathrm{L})$ at Igbogo which was found to be higher than the stated standard for NAFDAC. The river samples at Usen and Iguvinyoba, up and downstream (tables 4-7), indicates that the analysed samples are far less than the set standard of NAFDAC and WHO except for the concentration of Iron $(1.48 \mathrm{mg} / \mathrm{L})$ which met the required standard for both organizations. The above table are the various result obtained from the analysis of the different water samples collected in the study area include four (4) borehole (ground water), and three (3) river samples (surface water), from the analysis the concentration of most of the parameters are relatively small, while some like $\mathrm{Cd}, \mathrm{Ni}, \mathrm{Pb}$ and $\mathrm{V}$, were not detected.

Table 1: Physicochemical and Geochemical parameters of borehole sample from Okada

\begin{tabular}{|c|c|c|c|}
\hline Parameters & Concentration & $\begin{array}{l}\text { NAFDAC } \\
\text { Standard } \\
\end{array}$ & $\begin{array}{l}\text { WHO } \\
\text { Standard }\end{array}$ \\
\hline $\mathrm{pH}$ & 4.9 & $6.5-8.5$ & $6.5-9.5$ \\
\hline $\mathrm{EC}(\mathrm{US} / \mathrm{cm})$ & 94 & 1000 & 1200 \\
\hline Salinity $(\mathrm{g} / \mathrm{L})$ & 0.042 & - & - \\
\hline col.(pt.co) & 1 & - & 14 \\
\hline Turb.(NTU) & 1 & 5.0 & 5.0 \\
\hline $\mathrm{TSS}(\mathrm{mg} / \mathrm{L})$ & 2 & - & 25 \\
\hline $\mathrm{TDS}(\mathrm{mg} / \mathrm{L})$ & 47 & 500 & 1500 \\
\hline $\mathrm{COD}(\mathrm{mg} / \mathrm{L})$ & 12.0 & - & - \\
\hline $\mathrm{HCO}_{3}^{-2}(\mathrm{mg} / \mathrm{L})$ & 18.3 & - & 500 \\
\hline $\mathrm{Ca}^{+2}(\mathrm{mg} / \mathrm{L})$ & 0.05 & 75 & 200 \\
\hline $\mathrm{Na}^{+1}(\mathrm{mg} / \mathrm{L})$ & 3.37 & - & 200 \\
\hline $\mathrm{Mg}^{+2}(\mathrm{mg} / \mathrm{L})$ & 1.56 & 20 & 20 \\
\hline $\mathrm{K}^{+1}(\mathrm{mg} / \mathrm{L})$ & 0.16 & 10.0 & - \\
\hline $\mathrm{Cl}^{-1}(\mathrm{mg} / \mathrm{L})$ & 13.29 & 100 & 250 \\
\hline $\mathrm{PO}_{4}^{-3}(\mathrm{mg} / \mathrm{L})$ & 0.124 & - & - \\
\hline $\mathrm{NH}_{4} \mathrm{~N}(\mathrm{mg} / \mathrm{L})$ & 0.089 & - & - \\
\hline $\mathrm{SO}_{4}^{-2}(\mathrm{mg} / \mathrm{L})$ & 0.10 & 100 & 500 \\
\hline $\mathrm{Fe}^{+2}(\mathrm{mg} / \mathrm{L})$ & 0.08 & 0.3 & 1.00 \\
\hline $\mathrm{Mn}^{+2}(\mathrm{mg} / \mathrm{L})$ & 0.004 & 3.0 & 5 \\
\hline $\mathrm{Zn}^{+2}(\mathrm{mg} / \mathrm{L})$ & 0.05 & 5.00 & 3.00 \\
\hline $\mathrm{Cu}^{+2}(\mathrm{mg} / \mathrm{L})$ & 0.02 & 1.00 & 2.00 \\
\hline 2. $\operatorname{colcfc} / 100 \mathrm{~mL}$ & 1 & & \\
\hline Fungi/yeast & 0 & & \\
\hline $\mathrm{CFC} / 100 \mathrm{~mL}$ & & & \\
\hline $\mathrm{TVBC} / \mathrm{CFC}$ & 3 & & \\
\hline$/ 100 \mathrm{~mL}$ & & & \\
\hline $\mathrm{Cr}^{+3}(\mathrm{mg} / \mathrm{L})$ & 0.002 & - & 0.01 \\
\hline $\mathrm{Cd}^{+2}(\mathrm{mg} / \mathrm{L})$ & ND & - & - \\
\hline $\mathrm{Ni}^{+1}(\mathrm{mg} / \mathrm{L})$ & ND & - & 0.02 \\
\hline $\mathrm{Pb}^{+2}(\mathrm{mg} / \mathrm{L})$ & ND & 100 & 0.01 \\
\hline $\mathrm{V}^{+3}(\mathrm{mg} / \mathrm{L})$ & ND & - & - \\
\hline THC & 0.002 & & \\
\hline
\end{tabular}

This could be attributed to the absence of industrial activities in the area. The $\mathrm{pH}$ of the samples shows that the water in the study areas is slightly acidic of all the parameters analyzed one that is very significant when compared with standard for its concentration is iron. Iron $(\mathrm{Fe})$ content in the Usen River sample and Usen borehole sample ranges between 1.01-1.48 mg/L while that of Iguevinyoba River is about $1.19 \mathrm{mg} / \mathrm{L}$. This high concentration may be as a result of the underlying geology of the area, and may also be as a result of human activities, but the most likely cause is the geology of the area. Physicochemical analysis: The water samples from both borehole and river were analyzed and results obtained were compared to NAFDAC and WHO standard. The results of the physicochemical and geochemical parameters obtained from the analysis is extensively discussed under this section. $\mathrm{pH}$ value: Potential hydrogen $(\mathrm{pH})$ refers to how much hydrogen is mixed with water and it indicates the alkalinity or acidity of water on a logarithmic scale on which 7 is neutral.

Table 2: Physicochemical and Geochemical parameters of borehole sample from Iguobazuwa 


\begin{tabular}{|c|c|c|c|}
\hline Parameters & Concn. & $\begin{array}{l}\text { NAFDAC } \\
\text { Standard } \\
\end{array}$ & $\begin{array}{l}\text { WHO } \\
\text { Standard }\end{array}$ \\
\hline $\mathrm{pH}$ & 4.3 & $6.5-8.5$ & $6.5-9.5$ \\
\hline $\mathrm{EC}(\mathrm{US} / \mathrm{cm})$ & 159 & 1000 & 1200 \\
\hline Salinity $(\mathrm{g} / \mathrm{L})$ & 0.072 & - & - \\
\hline col.(pt.co) & 2 & - & 14 \\
\hline Turb.(NTU) & 1 & 5.0 & 5.0 \\
\hline $\mathrm{TSS}(\mathrm{mg} / \mathrm{L})$ & 1 & - & 25 \\
\hline TDS(MGLL) & 79 & 500 & 1500 \\
\hline $\mathrm{COD}(\mathrm{mg} / \mathrm{L})$ & 10.4 & - & - \\
\hline $\mathrm{HCO}_{3}^{-2}(\mathrm{mg} / \mathrm{L})$ & 12.2 & - & 500 \\
\hline $\mathrm{Ca}^{+2}(\mathrm{mg} / \mathrm{L})$ & 0.89 & 75 & 200 \\
\hline $\mathrm{Na}^{+1}(\mathrm{mg} / \mathrm{L})$ & 8.65 & - & 200 \\
\hline $\mathrm{Mg}^{+2}(\mathrm{mg} / \mathrm{L})$ & 3.82 & 20 & 20 \\
\hline $\mathrm{K}^{+1}(\mathrm{mg} / \mathrm{L})$ & 3.54 & 10.0 & - \\
\hline $\mathrm{Cl}^{-1}(\mathrm{mg} / \mathrm{L})$ & 8.86 & 100 & 250 \\
\hline $\mathrm{PO}_{4}^{-3}(\mathrm{mg} / \mathrm{L})$ & 0.450 & - & - \\
\hline $\mathrm{NH}_{4} \mathrm{~N}(\mathrm{mg} / \mathrm{L})$ & 0.040 & - & - \\
\hline $\mathrm{NO}_{3}{ }^{-1}(\mathrm{mg} / \mathrm{L})$ & 1.01 & 100 & 500 \\
\hline $\mathrm{SO}_{4}^{-2}(\mathrm{mg} / \mathrm{L})$ & ND & 0.3 & 1.00 \\
\hline $\mathrm{Fe}^{+2}(\mathrm{mg} / \mathrm{L})$ & 0.070 & 3.0 & 0.5 \\
\hline $\mathrm{Mn}^{+2}(\mathrm{mg} / \mathrm{L})$ & 0.04 & 3 & 5 \\
\hline $\mathrm{Zn}^{+2}(\mathrm{mg} / \mathrm{L})$ & 0.02 & 1.00 & 2.00 \\
\hline $\mathrm{Cu}^{+2}(\mathrm{mg} / \mathrm{L})$ & 0.003 & - & 0.01 \\
\hline $\mathrm{Cr}^{+3}(\mathrm{mg} / \mathrm{L})$ & ND & - & 0.01 \\
\hline $\mathrm{Cd}^{+2}(\mathrm{mg} / \mathrm{L})$ & ND & - & 0.02 \\
\hline $\mathrm{Ni}^{+1}(\mathrm{mg} / \mathrm{L})$ & ND & 0.01 & 0.01 \\
\hline $\mathrm{Pb}^{+2}(\mathrm{mg} / \mathrm{L})$ & ND & - & - \\
\hline $\mathrm{V}^{+3}(\mathrm{mg} / \mathrm{L})$ & 0.001 & & \\
\hline E.coli & 1 & & \\
\hline \multicolumn{4}{|l|}{$\mathrm{CFC} / 100 \mathrm{~mL}$} \\
\hline TVBCcfc/100mL & 2 & & \\
\hline
\end{tabular}

Therefore, groundwater from Okada town should be treated before consumption. Biological oxygen demand (BOD) is the measure of the quantity of oxygen consumed in the course of aerobic processes of decomposition of organic materials caused by microorganisms while chemical oxygen demand (COD) is the total amount of oxygen required to chemically oxidize both the biodegradable and nonbiodegradable organic matter. BOD determines how organic matter affects the concentration of dissolved oxygen (DO) in water.

Generally, a high BOD and COD indicates a high content of easily degradable and non-degradable organic matter in the water sample and this causes a decline in DO due to high demand of oxygen by the bacteria feeding on the organic material (Raji, et $a l, .2019)$.

In Table 1-7, it was observed that BOD and COD values obtained from all the water samples are below the WHO standard while DO values are above.

This implies that, there is no significant organic material present in the water to be decomposed by bacteria resulting to availability of enough oxygen in all the samples making the water safe for consumption.

Table 3: Physicochemical and Geochemical parameters of borehole

\begin{tabular}{llll}
\multicolumn{4}{c}{ sample from Igbogo } \\
\hline Parameters & Concn. & NAFDAC & WHO \\
& & Standard & Standard \\
\hline
\end{tabular}

\begin{tabular}{|c|c|c|c|}
\hline $\mathrm{pH}$ & 6.0 & $6.5-8.5$ & $6.5-9.5$ \\
\hline $\mathrm{EC}(\mathrm{US} / \mathrm{cm})$ & 88 & 1000 & 1200 \\
\hline Salinity $(g / L)$ & 0.040 & - & - \\
\hline col.(pt.Co) & 1.00 & - & 14 \\
\hline Turb.(NTU) & 1.00 & 5.0 & 5.0 \\
\hline $\mathrm{TSS}(\mathrm{mg} / \mathrm{L})$ & 1.00 & - & 25 \\
\hline TDS(mg/L) & 55 & 500 & 1500 \\
\hline $\mathrm{COD}(\mathrm{mg} / \mathrm{L})$ & 8.0 & - & - \\
\hline $\mathrm{HCO}_{3}(\mathrm{mg} / \mathrm{L})$ & 12.2 & - & 500 \\
\hline $\mathrm{Ca}^{+2}(\mathrm{mg} / \mathrm{L})$ & 0.66 & 75 & 200 \\
\hline $\mathrm{Na}^{+1}(\mathrm{mg} / \mathrm{L})$ & 3.45 & - & 200 \\
\hline $\mathrm{Mg}^{+2}(\mathrm{mg} / \mathrm{L})$ & 1.87 & 20 & 20 \\
\hline $\mathrm{K}^{+1}(\mathrm{mg} / \mathrm{L})$ & 0.67 & 10.0 & - \\
\hline $\mathrm{Cl}^{-}(\mathrm{mg} / \mathrm{L})$ & 8.0 & 100 & 250 \\
\hline $\mathrm{PO}_{4}{ }^{-3}(\mathrm{mg} / \mathrm{L})$ & 0.118 & - & - \\
\hline $\mathrm{NH}_{4} \mathrm{~N}(\mathrm{mg} / \mathrm{L})$ & 0.043 & - & - \\
\hline $\mathrm{NO}_{3}{ }^{-}(\mathrm{mg} / \mathrm{L})$ & 0.229 & 10 & 50 \\
\hline $\mathrm{SO}_{4}^{-2}(\mathrm{mg} / \mathrm{L})$ & 1.00 & 100 & 500 \\
\hline $\mathrm{Fe}^{+2}(\mathrm{mg} / \mathrm{L})$ & 0.95 & 0.3 & 1.00 \\
\hline $\mathrm{Mn}^{+2}(\mathrm{mg} / \mathrm{L})$ & 0.040 & 3 & 5 \\
\hline $\mathrm{Zn}^{+2}(\mathrm{mg} / \mathrm{L})$ & 0.035 & 5.0 & 3.0 \\
\hline $\mathrm{Cu}^{+2}(\mathrm{mg} / \mathrm{L})$ & 0.019 & 1.0 & 2.0 \\
\hline $\mathrm{Cr}^{+3}(\mathrm{mg} / \mathrm{L})$ & 0.002 & - & 0.07 \\
\hline $\mathrm{Cd}^{+2}(\mathrm{mg} / \mathrm{L})$ & ND & - & 0.07 \\
\hline $\mathrm{Ni}^{+1}(\mathrm{mg} / \mathrm{l})$ & ND & - & 0.02 \\
\hline $\mathrm{Pb}^{+2}(\mathrm{mg} / \mathrm{L})$ & ND & 0.07 & 0.01 \\
\hline $\mathrm{V}^{+3}(\mathrm{mg} / \mathrm{L})$ & ND & - & - \\
\hline $\mathrm{THC}$ & 0.001 & & \\
\hline $\begin{array}{l}\text { E.coli } \\
\text { cfc/100mL }\end{array}$ & ND & & \\
\hline Fungi/yeast & 0.00 & & \\
\hline $\begin{array}{l}\mathrm{CFC} / 100 \mathrm{~mL} \\
\text { TVBCcfc/100mL }\end{array}$ & 2 & & \\
\hline
\end{tabular}

The values of turbidity, total suspended solids (TSS) total dissolved solids (TDS), electrical conductivity (EC) and salinity are all below the acceptable limit value of WHO and NAFDAC standard with a maximum acceptable limit of 25 and 1500 both for TSS and TDS and 500 for TDS NAFDAC standard

Phosphates, Nitrates, Sulphates and Manganese contents: Phosphate is not harmful to humans but too much of it in drinking water speeds up eutrophication which in turn reduces the water dissolved oxygen. From tables 1-6, it is observed that the concentration of phosphate, sulphates, nitrates and manganese in the samples range between $(0.0310-0.450) \mathrm{mg} / \mathrm{L},(0.05-$ $1.01) \mathrm{mg} / \mathrm{L},(0.021-1.0) \mathrm{mg} / \mathrm{L}$ and $(0.01-0.41) \mathrm{mg} / \mathrm{L}$ respectively which are far below the permissible limit specified by WHO and NAFDAC in drinking water. Nitrate is an inorganic compound that is found in groundwater through septic systems and fertilizers run-off. Nitrate naturally does not pose a threat except when it is reduced to nitrites. Presence of nitrates in drinking water above $45 \mathrm{mg} / \mathrm{L}$ causes "blue baby" disease in infants according to WHO standard. Nitrates low concentration could be as a result of low farming activities in the selected area which could result to release of nitrates from fertilizers.

Table 4: Physicochemical and Geochemical parameters of borehole sample from Usen

\begin{tabular}{llll}
\hline Parameters & Concn. & $\begin{array}{l}\text { NAFDAC } \\
\text { Standard }\end{array}$ & $\begin{array}{l}\text { WHO } \\
\text { Standard }\end{array}$ \\
\hline $\mathrm{PH}$ & 5.6 & $6.5-8.5$ & $6.5-9.5$
\end{tabular}


Physicochemical and Hydrogeological Characteristics.....

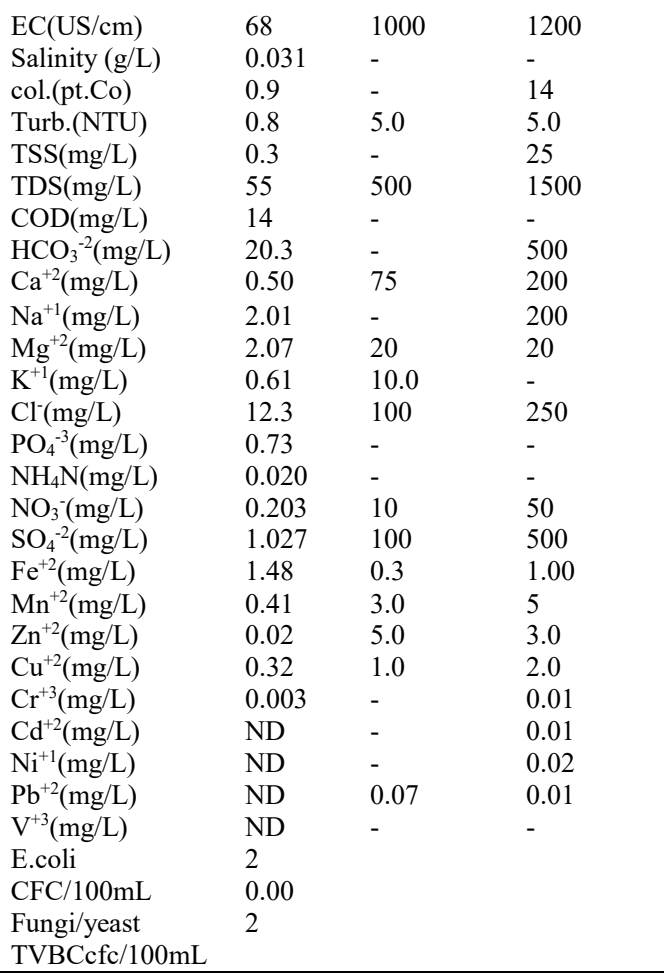

Human exposure to manganese concentrations higher than $5 \mathrm{mg} / \mathrm{L}$ in water can lead to severe disorders in nervous system, memory loss and depression as specified by WHO.

Calcium, Sodium and chloride contents of water samples from study area: The maximum concentration of calcium and sodium in all the samples analysed was $1.27 \mathrm{mg} / \mathrm{L}$ (in Usen) and (8.65) $\mathrm{mg} / \mathrm{L}$ accordingly.

By implication, groundwater in Okada and environs is soft water and it is below the WHO guidelines for both sodium and calcium and as such would need some sort of treatment for the stated cations. Chloride occurs naturally as elements and it is common in natural water.

Chloride in drinking water is not harmful, however, higher concentration above $250 \mathrm{mg} / \mathrm{L}$ and $100 \mathrm{mg} / \mathrm{l}$ for WHO and NAFDAC accordingly can cause unpleasant taste and corrosion which results to leaching of metals from the pipes used for water system distribution. The chloride levels in all water samples obtained are within the permissible limit of WHO standard.

Table 5: Physicochemical and Geochemical parameters of river sample

\begin{tabular}{llll}
\multicolumn{4}{c}{ from Usen } \\
\hline Parameters & Concn. & $\begin{array}{l}\text { NAFDAC } \\
\text { Standard }\end{array}$ & $\begin{array}{l}\text { WHO } \\
\text { Standard }\end{array}$ \\
\hline $\mathrm{pH}$ & & $6.5-8.5$ & $6.5-9.5$ \\
$\mathrm{EC}(\mathrm{NS} / \mathrm{cm})$ & 5.8 & 1000 & 1200 \\
Salinity $(\mathrm{g} / \mathrm{L})$ & 108 & - & - \\
\hline
\end{tabular}

\begin{tabular}{|c|c|c|c|}
\hline col.(pt.co) & 6 & - & 14 \\
\hline Turb.(NTU) & 3 & 5.0 & 5.0 \\
\hline $\mathrm{TSS}(\mathrm{mg} / \mathrm{L})$ & 9 & - & 25 \\
\hline $\mathrm{TDS}(\mathrm{mg} / \mathrm{L})$ & 54 & 500 & 1500 \\
\hline $\mathrm{COD}(\mathrm{mg} / \mathrm{L})$ & 20.0 & - & - \\
\hline $\mathrm{HCO}_{3}^{-2}(\mathrm{mg} / \mathrm{L})$ & 54.9 & - & 500 \\
\hline $\mathrm{Ca}^{+2}(\mathrm{mg} / \mathrm{L})$ & 1.27 & 75 & 200 \\
\hline $\mathrm{Na}^{+}(\mathrm{mg} / \mathrm{L})$ & 4.90 & - & 200 \\
\hline $\mathrm{Mg}^{+2}(\mathrm{mg} / \mathrm{L})$ & 4.68 & 20 & 20 \\
\hline $\mathrm{K}^{+}(\mathrm{mg} / \mathrm{L})$ & 0.91 & 10.0 & - \\
\hline $\mathrm{Cl}^{-}(\mathrm{mg} / \mathrm{L})$ & 13.290 .356 & 100 & 250 \\
\hline $\mathrm{PO}_{4}^{-3}(\mathrm{mg} / \mathrm{L})$ & 0.030 & - & - \\
\hline $\mathrm{NH}_{4} \mathrm{~N}(\mathrm{mg} / \mathrm{L})$ & 0.201 & - & - \\
\hline $\mathrm{NO}_{3}^{-}(\mathrm{mg} / \mathrm{L})$ & 0.050 & 10 & 50 \\
\hline $\mathrm{Fe}^{+2}(\mathrm{mg} / \mathrm{L})$ & 0.04 & 0.3 & 1.00 \\
\hline $\mathrm{Mn}^{+2}(\mathrm{mg} / \mathrm{L})$ & 0.01 & 3 & 5.00 \\
\hline $\mathrm{Zn}^{+2}(\mathrm{mg} / \mathrm{L})$ & 0.001 & 1.00 & 2.00 \\
\hline $\mathrm{Cu}^{+2}(\mathrm{mg} / \mathrm{L})$ & $\mathrm{ND}$ & - & 0.01 \\
\hline $\mathrm{Cr}^{+3}(\mathrm{mg} / \mathrm{L})$ & ND & - & 0.01 \\
\hline $\mathrm{Ni}(\mathrm{mg} / \mathrm{L})$ & ND & - & 0.02 \\
\hline $\mathrm{Pb}^{+2}(\mathrm{mg} / \mathrm{L})$ & ND & 0.01 & 0.01 \\
\hline $\mathrm{V}^{+3}(\mathrm{mg} / \mathrm{L})$ & 0.011 & - & - \\
\hline THC & - & 3 & \\
\hline E.coli & - & & \\
\hline $\mathrm{CFC} / 100 \mathrm{~mL}$ & 2 & & \\
\hline fungi/yeast & - & & \\
\hline TVBCcfc $/ 100 \mathrm{~mL}$ & 7 & & \\
\hline
\end{tabular}

Heavy metal contents in the study Area: The permissible limit set by WHO for Lead in drinking water is $0.01 \mathrm{mg} / \mathrm{L}$ and $0.07 \mathrm{mg} / \mathrm{l}$ for NAFDAC. In all the samples analyzed, it was observed that no trace of lead was found exception Iguvinyoba River (downstream) with a concentration of $0.001 \mathrm{mg} / \mathrm{L}$. This could be related to anthropogenic activities in the selected areas of the community such as mining practices, improper disposed of batteries, industrial wastes, smelting facilities and zero leachate of lead from the plumbing materials. Thus, the water from Okada community town is safe for drinking (Raji, et al., 2019). The WHO standard for Cadmium, Chromium and Nickel are $(0.01,0.01$ and 0.02$) \mathrm{mg} / \mathrm{L}$ respectively. However, no trace of these heavy metals were found in the study area. This could be attributed to unavailability of industries that employs these heavy metals as raw materials and/or effluent waste are not sited in the area.

Quality and Availability of Water in the Study Area: The state of water and it chemistry determines its potential use for domestic, agricultural, and industrial purposes. From the result obtained from the surface and groundwater samples analyzed in the area, in terms of quality, the water from boreholes in the study area is below the WHO standard for drinking water. The concentration in the river sample was somewhat similar to that of the borehole samples.

Table 6: Physicochemical and Geochemical parameters of river sample

\begin{tabular}{llll}
\multicolumn{4}{c}{ from Iguvinyoba $(\mathrm{Up}$-stream) } \\
\hline Parameters & Concn. & $\begin{array}{l}\text { NAFDAC } \\
\text { Standard }\end{array}$ & $\begin{array}{l}\text { WHO } \\
\text { Standard }\end{array}$ \\
\hline $\mathrm{pH}$ & & $6.5-8.5$ & $6.5-9.5$ \\
$\mathrm{EC}(\mathrm{US} / \mathrm{cm})$ & 5.3 & 1000 & 1200 \\
Salinity $(\mathrm{g} / \mathrm{L})$ & 69 & - & - \\
\hline
\end{tabular}




\begin{tabular}{llll}
\hline col.(pt.Co) & 0.7 & - & 14 \\
Turb.(NTU) & 1.1 & 5.0 & 5.0 \\
$\mathrm{TSS}(\mathrm{mg} / \mathrm{L})$ & 5 & - & 25 \\
$\mathrm{TDS}(\mathrm{mg} / \mathrm{L})$ & 45 & 500 & 1500 \\
$\mathrm{COD}(\mathrm{mg} / \mathrm{L})$ & 9 & - & - \\
$\mathrm{HCO}{ }^{-2}(\mathrm{mg} / \mathrm{L})$ & 32 & - & 500 \\
$\mathrm{Ca}^{+2}(\mathrm{mg} / \mathrm{L})$ & 0.01 & 75 & 200 \\
$\mathrm{Na}^{+1}(\mathrm{mg} / \mathrm{L})$ & 4.10 & - & 200 \\
$\mathrm{Mg}^{2}(\mathrm{mg} / \mathrm{L})$ & 4.32 & 20 & 20 \\
$\mathrm{~K}^{+1}(\mathrm{mg} / \mathrm{L})$ & 1.15 & 10.0 & - \\
$\mathrm{Cl}^{-}(\mathrm{mg} / \mathrm{L})$ & 12.10 & 100 & 250 \\
$\mathrm{PO}_{4}^{-3}(\mathrm{mg} / \mathrm{L})$ & 0.010 & - & - \\
$\mathrm{NH}_{4} \mathrm{~N}(\mathrm{mg} / \mathrm{L})$ & 0.038 & - & - \\
$\mathrm{NO}_{3}^{-}(\mathrm{mg} / \mathrm{L})$ & 0.203 & 10 & 50 \\
$\mathrm{SO}_{4}^{-2}(\mathrm{mg} / \mathrm{L})$ & 0.021 & 100 & 500 \\
$\mathrm{Fe}^{+2}(\mathrm{mg} / \mathrm{L})$ & 1.19 & 0.3 & 1.00 \\
$\mathrm{Mn}^{+2}(\mathrm{mg} / \mathrm{L})$ & 0.079 & 3.0 & 5 \\
$\mathrm{Zn}^{+2}(\mathrm{mg} / \mathrm{L})$ & 0.03 & 5.0 & 3.0 \\
$\mathrm{Cu}^{+2}(\mathrm{mg} / \mathrm{L})$ & 0.02 & 1.0 & 2.0 \\
$\mathrm{Cr}^{+2}(\mathrm{mg} / \mathrm{l})$ & - & - & 0.01 \\
$\mathrm{Cd}^{+2}(\mathrm{mg} / \mathrm{L})$ & - & - & 0.01 \\
$\mathrm{Ni}^{+1}(\mathrm{mg} / \mathrm{L})$ & - & - & 0.02 \\
$\mathrm{~Pb}^{+2}(\mathrm{mg} / \mathrm{L})$ & - & 0.07 & 0.01 \\
$\mathrm{~V}^{+2}(\mathrm{mg} / \mathrm{L})$ & - & - & - \\
$\mathrm{E} . c o l i^{c o l i}$ & 3 & & \\
$\mathrm{cfc}^{2} / 100 \mathrm{~mL}$ & 2 & & \\
fungi/yeast & & & \\
$\mathrm{TVBCcfc}^{2} / 100 \mathrm{~mL}$ & & & \\
\hline
\end{tabular}

Table 7: Physicochemical and Geochemical parameters of river from

\begin{tabular}{|c|c|c|c|}
\hline \multicolumn{4}{|c|}{ Iguvinyoba (Down-stream) } \\
\hline Parameters & Concn. & $\begin{array}{l}\text { NAFDAC } \\
\text { Standard } \\
\end{array}$ & $\begin{array}{l}\text { WHO } \\
\text { Standard }\end{array}$ \\
\hline $\mathrm{pH}$ & 5.3 & $6.5-8.5$ & $6.5-9.5$ \\
\hline $\mathrm{EC}(\mathrm{US} / \mathrm{cm})$ & 68 & 1000 & 1200 \\
\hline Salinity $(\mathrm{g} / \mathrm{L})$ & 0.034 & - & - \\
\hline Col.(Pt.Co) & 1 & - & 14 \\
\hline Turb.(NTU) & 1.1 & 5.0 & 5.0 \\
\hline $\mathrm{TSS}(\mathrm{mg} / \mathrm{L})$ & 6.1 & - & 25 \\
\hline $\mathrm{TDS}(\mathrm{mg} / \mathrm{L})$ & 45.8 & 500 & 1500 \\
\hline $\mathrm{COD}(\mathrm{mg} / \mathrm{L})$ & 8.8 & - & - \\
\hline $\mathrm{HCO}_{3}^{-2}(\mathrm{mg} / \mathrm{L})$ & 35 & - & 500 \\
\hline $\mathrm{Ca}^{+2}(\mathrm{mg} / \mathrm{L})$ & 0.01 & 75 & 200 \\
\hline $\mathrm{Na}^{+1}(\mathrm{mg} / \mathrm{L})$ & 4.4 & - & 200 \\
\hline $\mathrm{Mg}^{+2}(\mathrm{mg} / \mathrm{L})$ & 4.30 & 20 & 20 \\
\hline $\mathrm{K}^{+1}(\mathrm{mg} / \mathrm{L})$ & 1.20 & 10.0 & - \\
\hline $\mathrm{Cl}^{-}(\mathrm{mg} / \mathrm{L})$ & 12.70 & 100 & 250 \\
\hline $\mathrm{PO}_{4}^{-3}(\mathrm{mg} / \mathrm{L})$ & 0.010 & - & - \\
\hline $\mathrm{NH}_{4} \mathrm{~N}(\mathrm{mg} / \mathrm{L})$ & 0.38 & - & - \\
\hline $\mathrm{NO}_{3}^{-}(\mathrm{mg} / \mathrm{L})$ & 0.301 & 1 & 5 \\
\hline $\mathrm{SO}_{4}^{-2}(\mathrm{mg} / \mathrm{L})$ & 0.025 & 100 & 500 \\
\hline $\mathrm{Fe}^{+2}(\mathrm{mg} / \mathrm{L})$ & 1.20 & 0.3 & 1.00 \\
\hline $\mathrm{Mn}^{+2}(\mathrm{mg} / \mathrm{L})$ & 0.085 & 3.0 & 5 \\
\hline $\mathrm{Zn}^{+2}(\mathrm{mg} / \mathrm{L})$ & 0.03 & 5.0 & 3.0 \\
\hline $\mathrm{Cu}^{+2}(\mathrm{mg} / \mathrm{L})$ & 0.03 & 1.0 & 2.0 \\
\hline $\mathrm{Cr}^{+3}(\mathrm{mg} / \mathrm{L})$ & - & - & 0.01 \\
\hline $\mathrm{Cd}^{+2}(\mathrm{mg} / \mathrm{L})$ & - & - & 0.01 \\
\hline $\mathrm{Ni}^{+}(\mathrm{mg} / \mathrm{L})$ & - & - & 0.02 \\
\hline $\mathrm{Pb}^{+2}(\mathrm{mg} / \mathrm{L})$ & 0.001 & 0.07 & 0.01 \\
\hline $\mathrm{V}^{+3}(\mathrm{mg} / \mathrm{L})$ & - & - & - \\
\hline E.Coli & 2 & & \\
\hline $\mathrm{cfc} / 100 \mathrm{~mL}$ & 2 & & \\
\hline Fungi/yeast & & & \\
\hline TVBCcfc $/ 100 \mathrm{~mL}$ & & & \\
\hline
\end{tabular}

A few adverse iron concentration were noticed, which may be attributed to the underlying geology of the study area. On a general note, the quality of groundwater in the study area is fit for domestic, industrial and agricultural purposes, with little or no treatment needed. This could be attributed to the depth and the absence of industrial activities in the study area. The water in Usen river, Iguevinyoba river etc, has somewhat objectionable color and it is turbid thus, the water might need to be treated before used for domestic purposes. Also the iron concentration of this river is equally high and also requires treatment. Water is available in its natural state in the study area as surface water such as rivers and underground water. But from observation quality water is not really available to occupant in the study area. The national average of per capital water supply of 63 liters per day for urban centers and 25 liters per day for rural communities which Okada and environ is an example, is inadequate. As pointed out by (Babatola, 1997), some state in Nigeria, average per capital water supply is as low as 18 liters for urban areas and 5 liters for rural areas. Water use in the study area, exceed the water supply. To meet this demand, inhabitants resumed to the old practice of trekking several kilometers daily to streams and river in search for water and in most case the water is of questionable quality. As evident in Usen, Ugbokun, Iguogun, while in the filed carrying out the project work.

Conclusion: This study assessed the physicochemical properties and heavy metal contents of Groundwater from boreholes and rivers in different locations in Okada town community. The water is acidic in nature and as such both borehole and river samples have $\mathrm{pH}$ values below the set limits of WHO and NAFDAC, hence the need for the neutralization of the borehole and river water mostly consumed for drinking in Okada town. Further examination could be carried out to assess the biological properties of the borehole water. Borehole litho-logs reveal that a two aquifer system exist in the study area with a confining layer, as revealed by Okada borehole litholog in the study area. The aquifer is relatively porous and it is characterized by relatively high permeability. Physiochemical and biological analysis for both ground and surface water within the study area reveals that the water is fit for both human and industrial and agricultural uses with little or no treatment. As the concentration of most of the parameter falls below the WHO and NAFDAC standard Magnesium, calcium, chlorides, sodium sulphates, phosphates, nitrates, together with the heavy metals are low and all below the required standard with observed presence of natural iron content present in the water in the recommended proportion by the stated organizations.

\section{REFERENCES}

Adeyemi, O; Opeyemi, A; Olufemi, D (2017). Groundwater: Quality Levels and Human Exposure, SW Nigeria. J. Environ. Geo. 10 (1-2); 23-29 
Doan, NH; Lo, VT; Duong, KV; Ta, TB; Ha, LP; Nguyen, DT; Nguyen, DS; Hoang, TG; Nguen, Thi Commune, Bac Kan Province, Vietnam. BioMed Res. Inter. 1: 1-7

Faiza ,T; Yenny, R, Sasmito ,D; Bagyo, Y; Amin ,SL (2018).The Analysis of the Physical and Chemical Properties of the Water Quality in the Rainy Season in the Sumber Maron River Kepanjen, Malang Indonesia. Res. Environ. 8(1): $1-5$

Gorde, SP., Jadhav, MV. (2013). Assessment of Water Quality Parameters: A Review Int. J. Eng. Res. Appl. 3(6):2029-2035

Imasuen, OI; Omorogieva, OM (2013). Comparative study of heavy metals Distribution in Mechanic Workshop and Refuse Dumpsite in Oluku and Otofure, Edo, South-Western Nigeria. J. Appl. Sci. Environ. Manage. 3 (17) 425-430

Lee, GF., Jones Lee, A., (2005). Public health, groundwater resource and environmental protection from MSW leachate pollution by single and double composite lined dry tomb landfills. Available at: http://www.members.aol.com/annejlee/DoublecompLF-Pro.pdf

Malaysia, NR; Siti, HA; Homayoonfard M; Ali NJ, Rehan M., Sadef Y; Nizami, AS (2015). Analysis of Physiochemical Parameters to Evaluate the Drinking Water Quality in the State of Perak. J. of Chem. Article ID 716125: 1-10.

Muhammad, M; Samira S; Faryal, A; Farrukh, J (2013). Assessment of Drinking Water Quality and its Impact on Residents Health in Bahawalpur City. Inter. J. of Humanities and Social Sci. 3(15): 114-128.

Nwankwoala, HO; Ngah, SA (2011).Groundwater Resources of Niger Delta: Quality implications and management considerations. Inter .J. of Water Res. Environ Energy. 6(5): 155-163.

Olasoji SO; Nather OO; Bayode, A; Joshua NE (2019). Water Quality Assessment of Surface and Groundwater Sources Using a Water Quality Index Method: A Case Study of a Peri-Urban Town in Southwest, Nigeria. Environments, 6 (23): $1-11$
Omorogieva, OM (2014). Geochemistry of some Heavy Metals in Contaminated Soils, Stream Sediments, and Plants; Sources, Environmental and Health Implications and Possible means of Remediation, Oluku and Environs as a Case Study. Unpublished M.Sc Thesis, Department of Geology, University of Benin, Nigeria, pp79

Omorogieva, OM; Imasuen, OI; Sanni, EB (2013). Analysis and concentration of Heavy Metals; Mercury, Nickel, Arsenic, Lead, Chromium and Cadmium in a waste currency dumpsite: Sources, Its Environmental Implications. J. Sci. Res. 12: 87-94

Raji, WA; Anih, CE; Obeta, PO, 2019. Assessment of Physicochemical Properties and Heavy Metals in Borehole Water Used For Drinking In Okada Town, Edo State, Nigeria. J. Appl. Sci. Environ. Manage. 23 (12) 2205-2209.

Sabrina, S, Daniela, P, Joseph MS; Martin, BN; (2013). Assessment of Physical-Chemical Drinking Water Quality in the Logone Valley (Chad-Cameroon). Sustainability. 5: 3060-3076.

Sasikaran, SA. (2012). Physical, Chemical and Microbial analysis of bottled drinking water. The Ceylon medical journal. 57: 111-116.

Sivaranjani S; Amitava, R; Samrath, S (2015). Water Quality Assessment with Water Quality Indices. Inter. J. of Biores. Sci. 2(2): 85-89.

Taruna, J; Alankrita, C (2013). Assessment of water quality and its effects on the health of residents of Jhunjhunu district, Rajasthan: A cross sectional study. J. Public Health and Epidemiology. 5(4): 186-191.

Vijaya L; Sai TK (2017). A study on assessment of groundwater quality and it suitability for drinking in Vuyyuru, Krishna (dist.), Andhra Pradesh. Inter. J. Energy. Dev. Res. 5(2):1662-166. 